\title{
Reducing cell-to-cell spacing for large-format lithium ion battery modules with aluminum or PCM heat sinks under failure conditions
}

\author{
Brittany Coleman, Jason Ostanek, John Heinzel \\ Machinery Research and Silencing Division, Naval Surface Warfare Center Philadelphia Division, \\ 5001 S. Broad St., Philadelphia, Pennsylvania, United States \\ Corresponding Author: Brittany Coleman, bcoleman@mckean-defense.com
}

\begin{abstract}
Thermal management is critical for large-scale, shipboard energy storage systems utilizing lithium-ion batteries. In recent years, there has been growing research in thermal management of lithium-ion battery modules. However, there is little information available on the minimum cell-to-cell spacing limits for indirect, liquid cooled modules when considering heat release during a single cell failure. For this purpose, a generic four-cell module was modeled using finite element analysis to determine the sensitivity of module temperatures to cell spacing. Additionally, the effects of different heat sink materials and interface qualities were investigated. Two materials were considered, a solid aluminum block and a metal/wax composite block. Simulations were run for three different transient load profiles. The first profile simulates sustained high rate operation where the system begins at rest and generates heat continuously until it reaches steady state. And, two failure mode simulations were conducted to investigate block performance during a slow and a fast exothermic reaction, respectively. Results indicate that composite materials can perform well under normal operation and provide some protection against single cell failure; although, for very compact designs, the amount of wax available to absorb heat is reduced and the effectiveness of the phase change material is diminished. The aluminum block design performed well under all conditions, and showed that heat generated during a failure is quickly dissipated to the coolant, even under the closest cell spacing configuration.
\end{abstract}

\section{Keywords}

Thermal management, lithium-ion batteries, thermal runaway, propagating failure, phase change materials, liquid cooling

\section{Introduction and Motivation}

Large-scale energy storage systems are being actively developed by the US Navy for shipboard use. Energy storage enables energy conservation on naval platforms by eliminating the requirement for redundancy in electric generation. Typically, two generators are operated simultaneously, albeit at reduced efficiency, in the event that one generator goes offline the other generator can pick up the load. For single generator operations, significant fuel savings are possible because the generator would operate closer to its optimal efficiency. However, energy storage is required to pick up the load if the single generator goes offline. Similarly, centralized energy storage may help conserve energy by enabling the use of high efficiency, multi-spool gas turbine generators. Single-spool gas turbine generators are able to maintain power quality during transient load changes, due to high rotating inertia. Multi-spool gas 
turbine generators, which are more efficient than single-spool generators, require power conditioning equipment to maintain power quality during large transient load changes. Energy storage provides a buffering capability to enable the use of multi-spool generators.

Lithium-ion (li-ion) batteries are an attractive solution for centralized shipboard energy storage due to their high power capability and high energy density. However, design of such systems requires especially significant attention to thermal management considering the much larger size of shipboard energy storage versus, for example, vehicle battery systems. Also, there are several unique aspects to large scale militarized systems which make thermal management critical to reliable operation. First, the batteries may be subjected to sustained high rate operations, in high temperature machinery spaces, with moderate temperature $\left(30-40^{\circ} \mathrm{C}\right)$ cooling fluid to remove excess heat. The load profiles may approach continuous cycling, with minimal cool-down periods. The system must be compact to fit within confined machinery spaces. Using large format cells reduces system footprint, but with increased cell size comes decreased surface area to volume ratio. Additionally, with large format cells comes an increased safety risk from having more energy that can be released during a single cell failure. The thermal management system must limit peak temperatures during normal operation to avoid capacity degradation. And, in the event of a cell failure, the thermal management system must prevent a propagating failure. For these reasons, the thermal management subsystem is critical to ensuring safe, reliable operation of the energy storage system.

Energy storage thermal management is an active field of research due to emerging markets such as electric vehicles, renewable energy integration, and utility grid stability. There are many studies investigating different thermal management techniques. Most studies seek to minimize temperature gradients and minimize power consumption of the thermal management system. However, there is a lack of information on the limits of cell-to-cell spacing and reducing system footprint for modules of large format cells, especially during a cell failure. The following literature survey highlights need to investigate the minimum cell spacing limits for an indirect liquid cooled module under failure conditions.

\section{Air Cooling}

Thermal management strategies for cooling lithium-ion batteries generally include: single-phase air cooling, single-phase liquid cooling, two-phase cooling (either liquid-vapor or solid-liquid), and hybrid approaches combining multiple methods. Air cooling is a simple approach for system integration, but the low conductivity and low heat capacity of air limit its use to low-rate operation, typically less than 5Crate [1] [2] [3] [4] [5] [6]. And, care must be taken to ensure uniform airflow distribution to avoid hot spots, as demonstrated by Liu et al. [1]. Wu et al. compared different cooling methods, including natural and forced air convection, for a single 12 Ah cylindrical cell. The authors found that core temperatures increased to undesirable levels under $0.5 \mathrm{C}$ discharge when cooled via natural convection [2]. Mohammadian and Zhang considered forced air cooling of 15 Ah prismatic cells using pin fin channels between adjacent cells [3]. The increase in effective heat transfer coefficient at the cell surface allowed the cells to operate at a $5 \mathrm{C}$-rate.

Xun et al. considered forced air cooling at low Reynolds numbers for a 20 Ah module consisting of either prismatic or cylindrical cells [4]. The authors recommend a minimum ratio of cooling channel to battery cell volume to operate at $2 \mathrm{C}$-rate. Fan et al. considered air cooling of an EV battery operated under an aggressive driving cycle, with an average heat generation rate of about $6 \mathrm{~W} /$ cell [5]. The authors 
systematically varied the gap spacing between adjacent prismatic cells, from $1 \mathrm{~mm}$ to $5 \mathrm{~mm}$, and determined the influence on peak temperatures, temperature uniformity, required fan power, and air flow distribution. Park et al. also consider an EV battery consisting of $20 \mathrm{Ah}$ prismatic cells [6]. The authors investigate details of flow distribution and minimizing pumping power, but also discuss the influence of the gap size between adjacent cells on thermal performance and pumping power.

Kizilel et al. performed simulations showing that a passive air cooled module was unable to prevent cellto-cell propagation after a single cell failure [7]. The influence of cell-to-cell spacing on propagating failure within air cooled modules is unclear, although Hatchard et al. discussed the importance of radiation heat transfer during thermal abuse of li-ion cells [8]. Determination of propagation risk should consider not only convective and conductive heat transfer, but also radiation heat transfer, which requires knowledge of the cell surface emissivity.

Although the present work focuses on liquid cooling of large format cells, this review of air cooled li-ion modules provides a general baseline for typical cell-to-cell spacing. For example, the spacing considered by Fan et al. [5] was 1 to $5 \mathrm{~mm}$ between adjacent cells. However, considering the conclusions of Kizelel et al. [7] and Hatchard et al. [8], further analysis would be required to determine the minimum air gap required to prevent propagating failure.

\section{Liquid Cooling}

Liquid cooling of lithium-ion cells is usually implemented in an indirect manner, where the coolant is not in direct contact with the cells but rather an intermediate material is used, such as a cold block or thermal ground plane. And, liquid cooling typically improves temperature uniformity, since the coolant heat capacity is greater than that of air. While most studies consider operation up to 5C-rate [1] [9] [10] [11], Smith et al. considered 25 Ah prismatic cells dissipating up to $40 \mathrm{~W} /$ cell, which is on the order of 10Crate [12]. The thermal management system consisted of liquid cooled plates surrounding the battery stack, and the focus of the study was on optimal design of the cold plates. The effect of cell spacing was not considered, nor the response to cell failure, which are the focus of the present work.

Liquid cooled modules of prismatic cells generally use one of three strategies: remove heat at the boundaries of the cell stack [12], remove heat between adjacent cells using thin coolant passages [1] [9] [10] [13] [14] [15], or remove heat at a thermal ground plane which may have conductive fins to transfer heat from within the stack down to the thermal ground plane [11]. Zhao et al., on the other hand, investigated the use of mini-channel jacket cooling for cylindrical cells [16], but do not consider cell spacing or response to cell failure in the analysis.

Jarrett and Kim designed and investigated a serpentine-channel cold plate and found that it met desired pressure and maximum temperature but did not perform as well in temperature variation [17]. Jarrett and Kim further studied the serpentine-channel cold plate to improve the design and determine the effect of boundary conditions [18]. They found that temperature variation optimization was the most sensitive and that battery heat flux and flow rate were negligible.

\section{Two-Phase Cooling (Liquid-Vapor) and Heat Pipes}

Utilizing phase-change allows for heat transfer at small temperature differences, which generally provides improved temperature uniformity compared to single-phase flow. Also, the formation of bubbles during 
boiling disrupts the thermal boundary layer, resulting in high heat transfer coefficients. Hirano et al. investigated direct two-phase cooling by submerging prismatic cells in an inert, dielectric hydrofluoroether (HFE) having low boiling point [19]. The cells were surrounded by a porous material to help wick fluid between adjacent cells. The study shows the high heat transfer rates possible with this cooling method as discharge rates reached 20C, although the cells considered were small format cells having capacity of $1 \mathrm{Ah}$ and did not consider response to failure mode. Although Hirano et al. showed good performance with direct two-phase cooling, the heat flux at the cell surface in the present study does not require this approach and only considers single-phase liquid cooling.

Heat pipes are a common method of implementing indirect two-phase cooling, and have been investigated for battery thermal management [20] [21] [22] [23] [24] [25]. Zhao et al. highlighted two important aspects of successful implementation of heat pipes: first, to ensure good thermal contact between cell and heat pipe and, second, to ensure that the condensing end of the heat pipe is adequately cooled [25]. Wu et al., who compared natural convection, forced air convection, and heat pipes, also confirmed that good thermal contact between cell and heat pipes was important to get full utilization of the heat pipes [2]. The use of heat pipes may provide an improvement to a solid aluminum heat sink, for example, but were not considered in the scope of the present work but may be considered in follow-on studies.

\section{Two-Phase Cooling (Solid-Liquid)}

Solid-liquid systems have also been implemented in battery thermal management applications [26] [27] [28] [29] [30]. Typically, wax is used as the phase change material (PCM), as first demonstrated by AlHallaj and Selman [31] [32]. Performance of PCM material may be improved by adding conductive filler or by impregnating PCM into a conductive medium such as expanded graphite [33] [34] [35] or metal foam [36] [37] [38] [39]. Kizilel et al. investigated small format cells surrounded by a wax composite material of expanded graphite and wax [7]. The authors showed that the latent heat of the wax helped prevent a propagating failure, where passive air cooling was unable to prevent propagation [7]. Qu et al. investigated a passive thermal management system with paraffin wax/copper foam composite PCM versus pure PCM and pure copper and found improved performance with the composite material [40] [41]. The work of $\mathrm{Qu}$ et al. does not consider the thickness of the heat sink material, and therefore, does not consider the effect of cell-to-cell spacing. Rather than using wax as the PCM, Zhao et al. used hydrogel between flat cells and showed improved performance under both normal and failure modes [42] [43]. The work of Kizilel et al. and Zhao et al. demonstrate the merit of using a PCM to absorb heat during a cell failure to prevent propagation. However, the effect of cell spacing remains unknown. And, there is no comparison of PCM versus a typical heat sink material (e.g. aluminum) in actively cooled modules under failure conditions. The present work aims to investigate these aspects of lithium-ion thermal management.

\section{Uniqueness of Present Work}

From this review, it is clear that there is an opportunity to explore the effect of cell spacing in response to cell failure with the goal of preventing propagation. It has been previously shown that passive cooling with wax composites may prevent propagating failure for small cells where passive cooling with natural convection could not prevent propagation [7]. And, other materials, such as hydrogels, can also improve thermal response to events like nail penetration [43]. However, the effect of cell spacing on response to 
cell failure for indirect liquid cooled modules using aluminum or wax composite materials remains unknown.

To address this gap in the literature, a two-dimensional finite element model is used to evaluate a generic, four-cell battery module. Two heat sink materials are considered: a solid aluminum block (AB) and a composite consisting of a porous, conductive material which is filled with varying amounts of wax (CW). The model accounts for the anisotropic conductivity of the battery cell, the thermal interfaces within the module, and latent heat storage of the heat sink material (for the composite). The results indicate the importance of block conductivity and interface quality on the module temperatures, temperature gradients, and conductive time scales. For the composite material, metal porosity and wax melting temperature are varied and compared with the effects of thermal interface quality. Cell spacing is varied to further examine these cold block characteristics. Finally, the present work is unique in demonstrating the importance of the aforementioned parameters in both normal and failure mode conditions. The remainder of the paper will discuss the cold block design and material properties, the numerical model and boundary conditions, and the results and conclusions drawn from the simulations.

\section{Cold Block Design and Material Properties}

Figure 1 shows the basic concept for a single-phase, liquid cooled design. This figure shows a single battery cell placed inside of a thermally conducting block which allows heat to be removed via liquid travelling within a nearby copper tube. Also shown is a one-dimensional thermal resistance network which represents the heat flow path from the battery core to the cooling fluid. The battery is represented by several RC-circuits connected in series. The resistor elements represent thermal resistance and the capacitor elements represent heat capacity. The battery is broken into several RC-circuits to illustrate the volumetric heat generation within the cell, where the current source symbols are analogous to heat generation. At the interface between the battery cell and the cold block, a single resistor element represents the thermal resistance from an electrically insulating, but thermally conducting interface material. This interface material may be a thin plastic material, such as polyimide, or an engineered thermal interface material or gap-pad. It is assumed that the interface is thin and has negligible heat capacity, such that a single resistor element is appropriate. Heat then flows through the cold block which is represented here as a single RC-element. A second thermal interface exists between the cold block and the copper tube. The copper tube wall is represented by a single RC-element. And, the last thermal resistance is associated with the convective heat transfer resistance to the cooling fluid. 


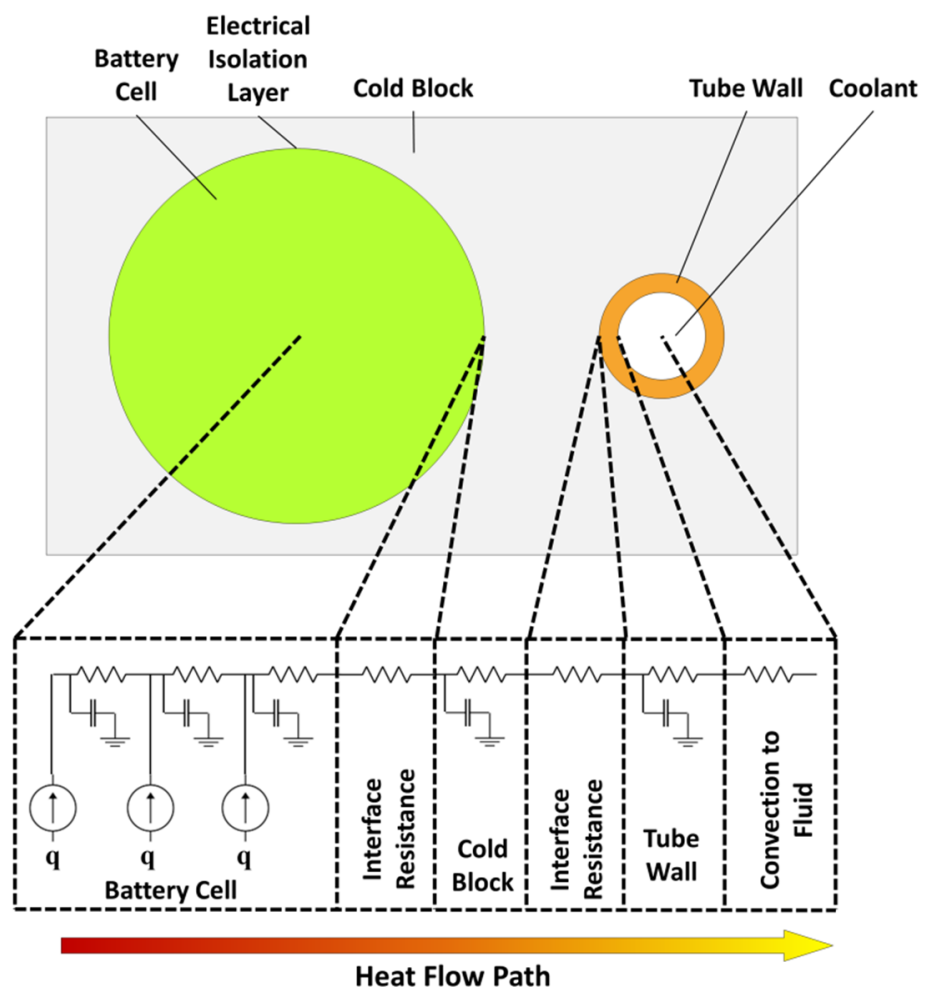

Figure 1: Planar view of a single cell and cooling tube representing a simplified indirect, liquid-cooling design. The one-dimensional thermal resistance network shows the heat flow path from cell core to the coolant. In this work, the cold block may either be a composite wax/metal material (CW) or a solid aluminum block $(A B)$.

The one-dimensional thermal resistance network in Figure 1 shows that there are at least five thermal resistance components between the boundary of the cell and the cooling medium. To be investigated in the present work is the relative importance of each component and the relative importance of heat capacity in comparison with thermal resistance. For instance, during steady or quasi-steady operation heat is generated continuously. In this case, minimizing thermal resistance between the cell and the cooling fluid will improve performance and result in lower core temperature of the cell. Alternatively, during a failure mode, there is a momentary release of heat which must not be allowed to spread to neighboring cells. In this case, heat flow may be limited between neighboring cells by an increased heat capacity in the cold block material or by increasing the thermal resistance for the pathway between cells. It is still desirable to maintain low thermal resistance along the pathway from cell to cooling fluid because the heat must ultimately be dissipated to the fluid. These two different scenarios indicate the importance of understanding the thermal behavior of a given cold block design under both normal operation and failure mode conditions. 


\subsection{Heat Conduction Equation and Model Verification}

ANSYS Mechanical APDL finite element software was used to solve the heat conduction equation in cylindrical coordinates:

$\rho C_{p}(T) \frac{\partial T}{\partial t}=\frac{1}{r} \frac{\partial}{\partial r}\left(k_{r} r \frac{\partial T}{\partial r}\right)+\frac{1}{r^{2}} \frac{\partial}{\partial \theta}\left(k_{\theta} \frac{\partial T}{\partial \theta}\right)+\dot{q}^{\prime \prime \prime}$

To model the latent heat of wax melting and solidification, a varying specific heat was used [44]:

$C_{p}(T)=C_{\infty}\left\{C_{1} \exp \left[a\left(T-T_{f}\right)^{2}\right]+1\right\}$

where $C_{\infty}$ is the specific heat capacity in both solid and liquid states, $C_{l}$ and $a$ are constants, and $T_{f}$ is the nominal melting temperature. The constants $C_{l}$ and $a$ are related to the material latent heat of formation:

$L_{f}=\int C_{1} \exp \left[a\left(T-T_{f}\right)^{2}\right] d T$

For a wax material having latent heat of $155 \mathrm{~kJ} / \mathrm{kg}$ and a nominal melting temperature of $57^{\circ} \mathrm{C}$, selecting constants $C_{l}=104.2$ and $a=-60$ gives an approximate melting range of $4{ }^{\circ} \mathrm{C}$ as shown in the specific heat curve of Figure 2.

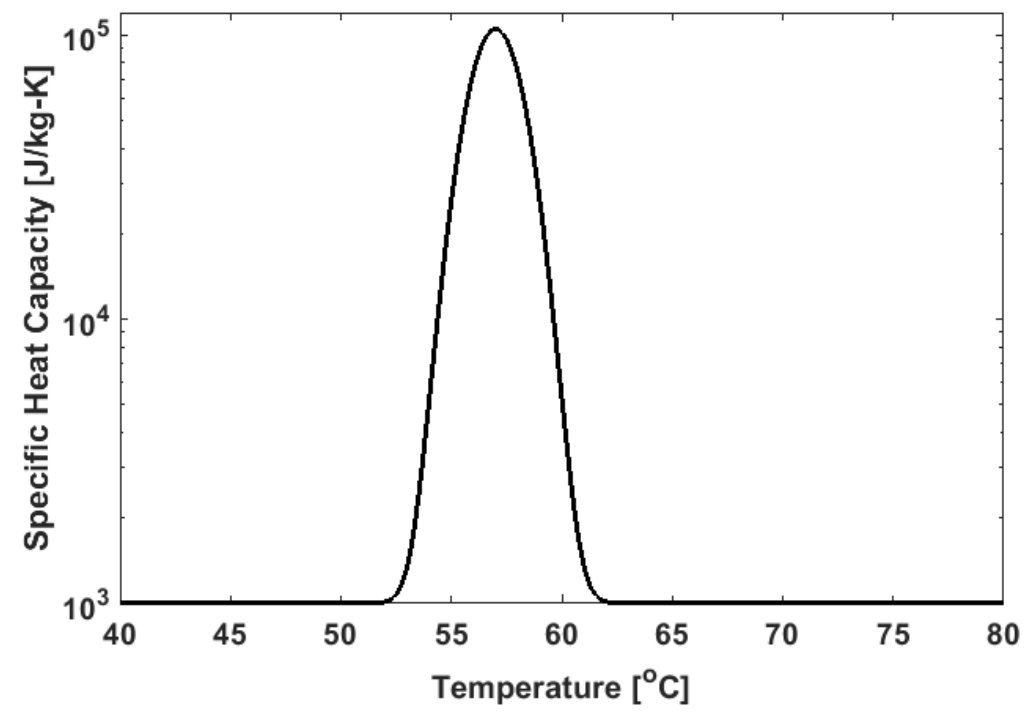

Figure 2: Temperature-dependent specific heat as a representation of latent heat.

In order to verify the finite element model, a numerical solution for $1 \mathrm{D}$ heat transfer in a slab was compared with the analytical solution developed by Chiba [44]. The slab was insulated at $x / L=0$ and a constant temperature boundary condition, $T_{w}=44^{\circ} \mathrm{C}$, was specified at $x / L=1$. The initial temperature was set to the nominal melting temperature of $T_{f}=57^{\circ} \mathrm{C}$. Figure 3 shows good agreement between the numerical and analytical solutions, only differing slightly at small time constants. 


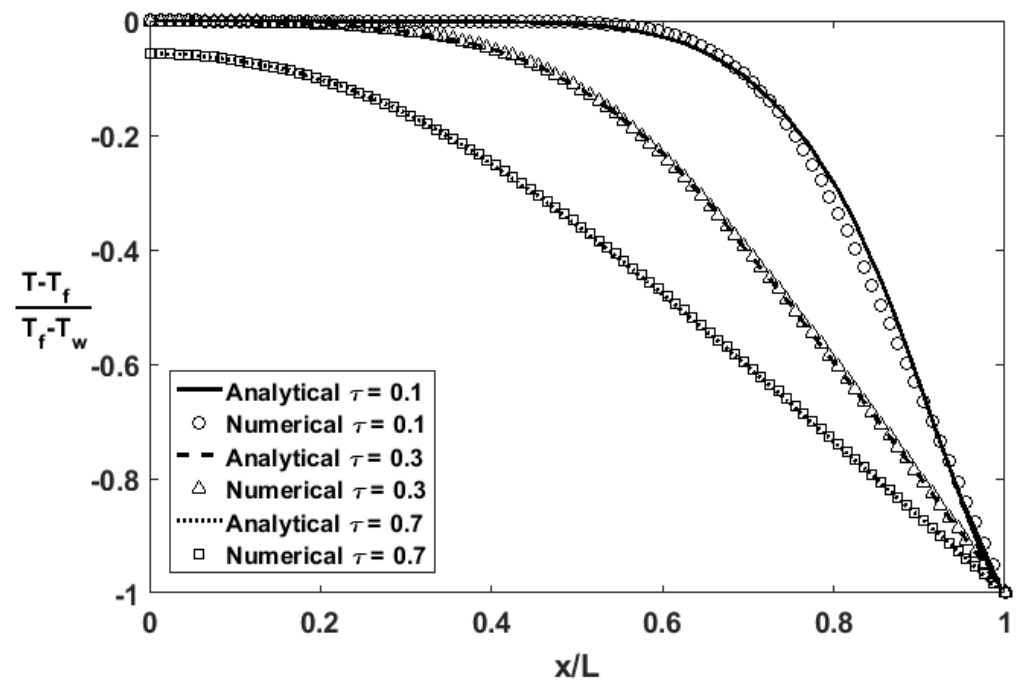

Figure 3: Model verification using numerical model (ANSYS) and analytical solution (Chiba [44]) at different non-dimensional times, $\tau=k \cdot t /\left(\rho \mathbf{C}_{\infty} \mathbf{L}^{2}\right)$.

\subsection{Geometry}

A generic four-cell module is considered, as shown in Figure 4. Also shown in Figure 4 is the twodimensional, unstructured mesh. Triangular, two-dimensional elements were used to more easily discretize the complex geometry. ANSYS supports both quadratic and linear 2D triangle elements. In this case, quadratic (second-order) elements were used for improved accuracy over the linear elements. The meshing and simulation were executed using scripts to facilitate quick simulation and design iteration.
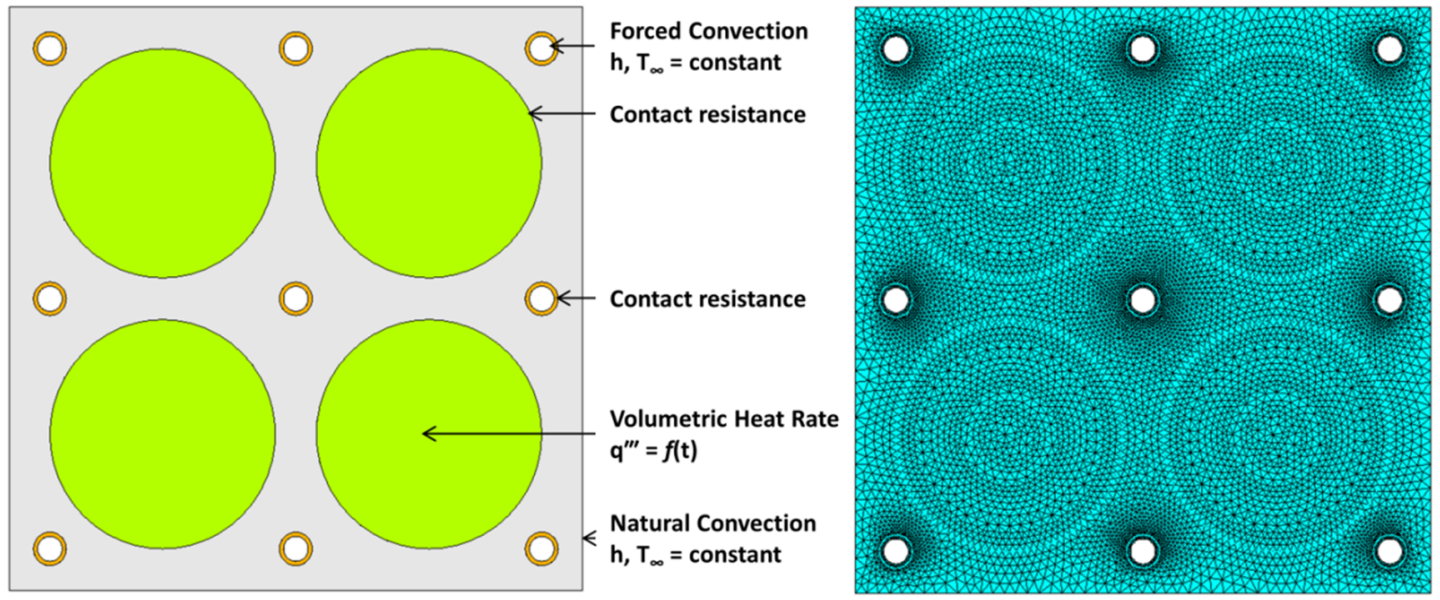

Figure 4: Cold block schematic, boundary conditions, and finite element mesh for $10 \mathrm{~mm}$ cell spacing.

The battery cells are assumed to have a diameter of $55 \mathrm{~mm}$. And, although the simulation was twodimensional, heat generation rates were calculated based on the assumption of the cell having length of $200 \mathrm{~mm}$ and capacity of $30 \mathrm{Ah}$. Nine copper cooling tubes were placed in the block, each having an inner diameter of $6 \mathrm{~mm}$ and an outer diameter of $8 \mathrm{~mm}$. Three different heat sink geometries were 
considered with differing cell to cell spacing. The three geometries are shown in Figure 5 and include: 10 mm spacing (large), $5 \mathrm{~mm}$ spacing (medium), and $1 \mathrm{~mm}$ spacing between cells (small).

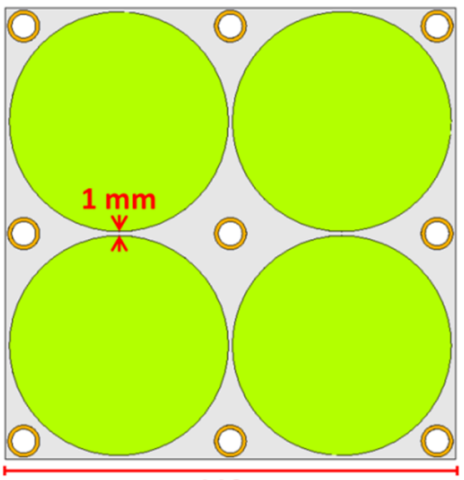

$113 \mathrm{~mm}$

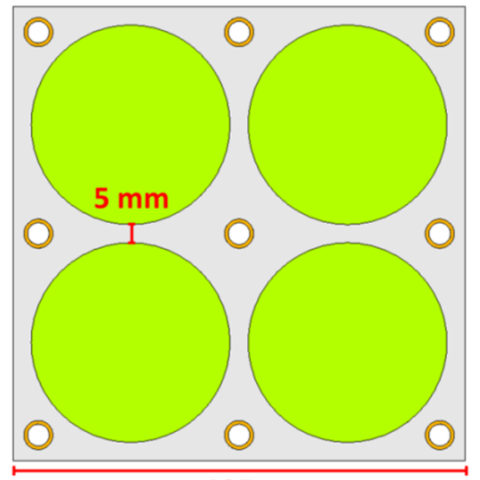

$125 \mathrm{~mm}$

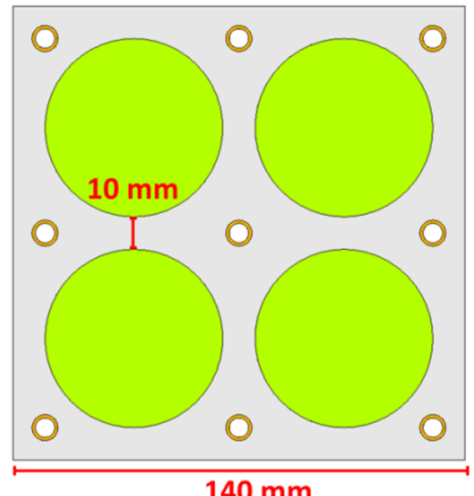

$140 \mathrm{~mm}$

Figure 5: Cold block schematic for each of the three geometries: small (1 mm spacing), medium (5 mm spacing), and large (10 $\mathrm{mm}$ spacing), from left to right.

\subsection{Material and Interface Properties}

The cells were modelled with a density of $\rho=2222 \mathrm{~kg} \cdot \mathrm{m}^{-3}$, a specific heat capacity of $C_{p}=1200 \mathrm{~J} \mathrm{~kg}^{-1} \mathrm{~K}^{-1}$, a radial conductivity of $k_{r}=0.633 \mathrm{~W} \cdot \mathrm{m}^{-1} \cdot \mathrm{K}^{-1}$, and an axial/circumferential conductivity of $k_{\theta}=k_{z}=48$ $\mathrm{W} \cdot \mathrm{m}^{-1} \cdot \mathrm{K}^{-1}$.

The material properties of cold block materials used in the modelling are given in Table 1. Four CW composite materials were evaluated at $5 \%, 10 \%, 20 \%$, and $30 \%$ metal loading by volume $(95 \%, 90 \%$, $80 \%$, and $70 \%$ porosity, respectively). The metal used in this case was copper, though composites using graphite have similar material properties. Thermal conductivity of the composite material was calculated using the model of Bhattacharya et al. for open cell foam metals impregnated with wax [45]. The melting temperature of the wax was assumed to occur at $57^{\circ} \mathrm{C}$. Block density and specific heat capacity $\left(C_{\infty}\right)$ were calculated using a simple mass-weighted average. The temperature-dependent specific heat curve, $C_{p}(T)$ was calculated by iteratively adjusting the constants, $C_{l}$ and $a$ from equation 2 , to represent the latent heat of fusion covering an approximate melting range of $4^{\circ} \mathrm{C}$. The $\mathrm{AB}$ heat sink material uses typical values for aluminum. 
Table 1: Thermal properties of heat sink materials.

\begin{tabular}{|lccccccc|}
\hline Description & Symbol & Units & AB & $\begin{array}{c}\text { CW } \\
\mathbf{5 \%}\end{array}$ & $\begin{array}{c}\text { CW } \\
\mathbf{1 0} \%\end{array}$ & $\begin{array}{c}\text { CW } \\
\mathbf{2 0} \%\end{array}$ & $\begin{array}{c}\text { CW } \\
\mathbf{3 0 \%}\end{array}$ \\
\hline Block conductivity & $\mathrm{k}$ & $\mathrm{W} \cdot \mathrm{m}^{-1} \cdot \mathrm{K}^{-1}$ & 167 & 13.2 & 26.2 & 52.2 & 78.2 \\
Block density & $\rho$ & $\mathrm{kg} \cdot \mathrm{m}^{-3}$ & 2700 & 1147.5 & 1545 & 2340 & 3135 \\
$\begin{array}{l}\text { Block specific heat } \\
\text { capacity }\end{array}$ & $\mathrm{C}_{\infty}$ & $\mathrm{J} \cdot \mathrm{kg}^{-1} \cdot \mathrm{K}^{-1}$ & 896 & 922 & 763 & 607 & 530 \\
$\begin{array}{l}\text { Block latent heat } \\
\text { Melting temperature }\end{array}$ & $\mathrm{L}_{\mathrm{f}}$ & $\mathrm{kJ} \cdot \mathrm{kg}^{-1}$ & $\mathrm{~N} / \mathrm{A}$ & 96.2 & 67.7 & 39.7 & 26.0 \\
& $\mathrm{~T}_{\mathrm{f}}$ & ${ }^{\circ} \mathrm{C}$ & $\mathrm{N} / \mathrm{A}$ & 57 & 57 & 57 & 57 \\
\hline
\end{tabular}

The interface properties evaluated in this study include the thermal interface resistance between the cells and the block and between the cooling tubes and the block. The interface quality is represented by the thermal contact conductance (TCC) having units of $\mathrm{W} \cdot \mathrm{m}^{-2} \mathrm{~K}^{-1}$, which is the inverse of interface resistance. In this work, the TCC was varied to determine its influence on heat sink performance. However, baseline TCC values were estimated at the cell-to-block and tube-to-block interfaces. The cell-to-block TCC is calculated for a 10 mil plastic film adhered to the cell in conjunction with a thermal grease or epoxy applied to the film. The cell would then be slid into the block, resulting in a close but not interfering fit. This gives a TCC value of $1000 \mathrm{~W} \cdot \mathrm{m}^{-2} \mathrm{~K}^{-1}$ which was applied to the cell-to-block interfaces in the ANSYS model. The cooling tube-to-block interface was assumed to be a higher quality interface, e.g. a press fit or a thin layer of thermal potting compound. For the tube-to-block interfaces, $5000 \mathrm{~W} \cdot \mathrm{m}^{-2} \mathrm{~K}^{-1}$ was applied to the ANSYS model.

\subsection{Boundary Conditions}

In addition to the geometric layout and mesh, Figure 4 indicates the boundary conditions used for the finite element modelling. These include forced convection in the cooling tubes, ambient convection on the outer edges of the block and heat generation within the cells.

The convection rate applied to the inner diameter of the cooling tubes was based on 50/50 propylene glycol water (PGW) flowing at a rate of $3 \mathrm{~L} \mathrm{~min}^{-1}$ to ensure turbulent flow. The resulting convection coefficient was calculated using turbulent flow correlations to be $3726 \mathrm{~W} \cdot \mathrm{m}^{-2} \mathrm{~K}^{-1}$. And, the flow Reynolds number was 3543 , which is above the laminar-to-turbulent transition of $\operatorname{Re}=2300$. The cooling fluid temperature, $40.7^{\circ} \mathrm{C}$, was calculated as the average of the $40{ }^{\circ} \mathrm{C}$ inlet temperature and the $41.4{ }^{\circ} \mathrm{C}$ steady state outlet temperature, calculated using an energy balance. Ambient convection on the outer walls of the block was set as $10 \mathrm{~W} \cdot \mathrm{m}^{-2} \mathrm{~K}^{-1}$ with an ambient temperature of $40{ }^{\circ} \mathrm{C}$. The remaining boundary condition was the volumetric heat generation rate applied to the cells. 


\subsection{Load Profiles}

To simulate a normal operating condition, it was assumed that the batteries were operating in a quasisteady manner such as a repeating charge/discharge cycle with no rest period. While charge and discharge produce different levels of heat generation, the system was modeled using an average heat generation rate of $65 \mathrm{~W}$. This heat load was applied to each cell at time, $\mathrm{t}=0 \mathrm{~s}$. The initial temperature of the module was uniform, $40^{\circ} \mathrm{C}$. The simulation was carried out to 10,000 seconds to ensure that the system had reached steady state. The heat generation rate of $65 \mathrm{~W}$ was chosen to represent a fairly high operational rate. Depending on the cell capacity and cell resistance, this heat generation rate is approximately bounded by $8 \mathrm{C}$-rate and $12 \mathrm{C}$-rate. For example, a $30 \mathrm{Ah}$ cell may have internal resistance of $0.6 \mathrm{~m} \Omega$ [46]. Therefore, the heat generation of $65 \mathrm{~W}$ corresponds to approximately $329 \mathrm{~A}$, or 11C-rate.

Two load profiles were generated to simulate cell failure, as shown in Figure 6. The first profile simulates a slow, low energy reaction which occurs over 300 seconds and releases approximately $50 \%$ of the cell's electrical energy. This load profile is based on independent experiments using adiabatic calorimetry during a thermal runaway. The second profile simulates a fast, high energy exothermic reaction which occurs over 5 seconds and releases $130 \%$ of the cell's electrical energy. In both failure mode profiles, the initial condition was taken from the steady state result of the normal operation profile. 

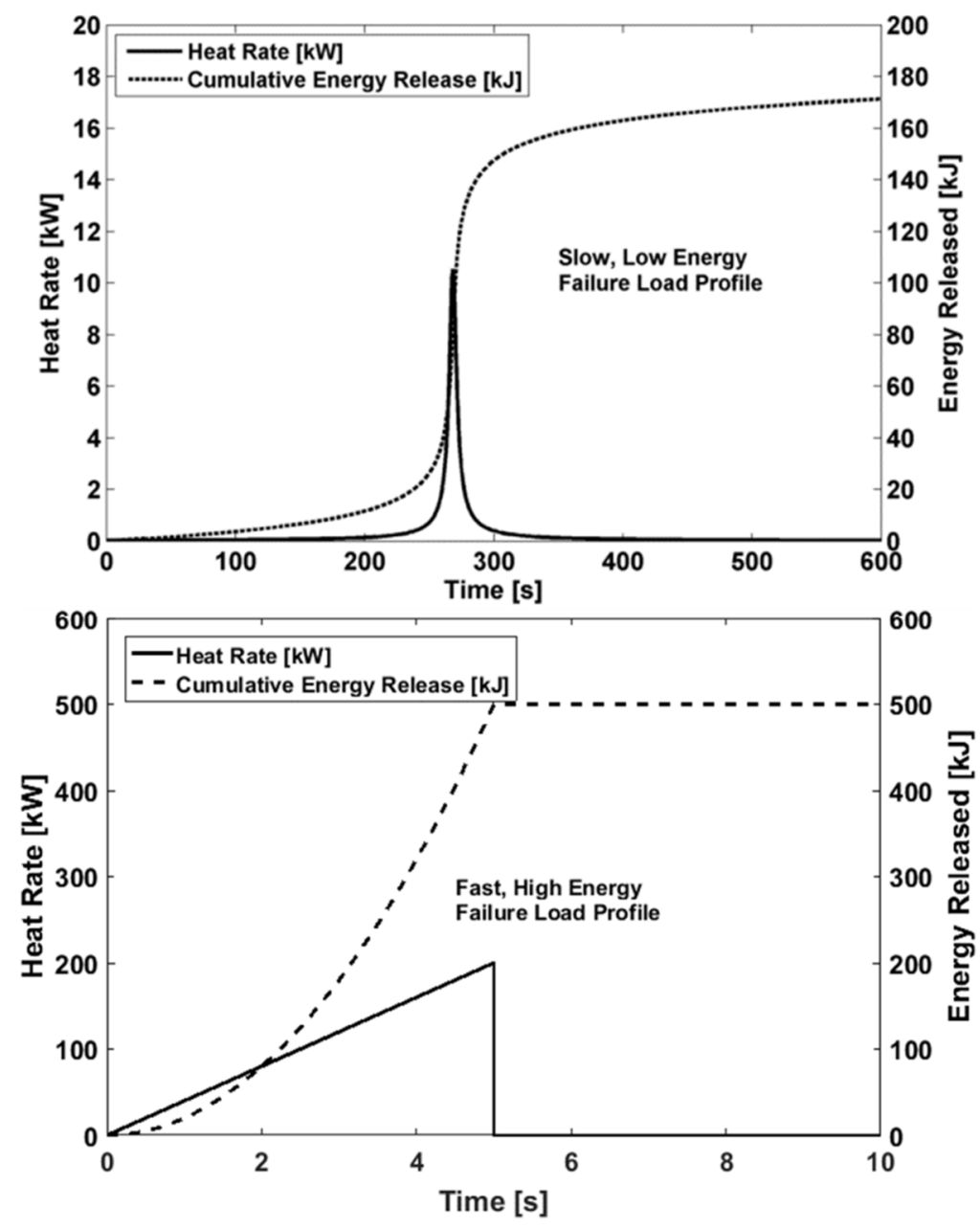

Figure 6: Load profiles: slow reaction (top) and fast reaction (bottom). The slow reaction profile was obtained from independent adiabatic calorimetry test data, heat was released over $\sim 30$ seconds, and energy release was $\sim 50 \%$ of electrical energy of the cell. The fast reaction profile was assumed to occur over 5 seconds and release $130 \%$ of the electrical energy of the cell.

In the low energy failure profile, it was assumed that this slow failure would be detected by the battery management system and that all cells in the module would be secured at the initiation of failure. Therefore, the neighboring cells switch from $65 \mathrm{~W}$ to zero heat generation at $\mathrm{t}=0 \mathrm{~s}$. Only the failed cell produces heat for $\mathrm{t}>0 \mathrm{~s}$. The shape of this heat release profile was determined from independent testing using adiabatic calorimetry for similar, large-format cells.

In the high energy, fast release profile, the failed cell releases energy over a five-second ramp profile. The amount of energy released was calculated based on the stored electrical energy at $100 \%$ state of charge plus an additional $30 \%$, to account for exothermic chemical reactions. It was assumed that the other cells remain in operation during the failure, continuing to generate $65 \mathrm{~W}$ for $\mathrm{t}>0 \mathrm{~s}$.

\section{Results}

\subsection{Normal Operation Mode Results}


The steady state results are shown in Figure 7 and Figure 8. In Figure 7, the core cell temperatures for each material are shown from initiation at $40^{\circ} \mathrm{C}$ to steady state. The temperature contour plots at steady state are illustrated in Figure 8. At steady state, the performance of the cold block is directly proportional to the thermal resistance between the cell cores and the coolant and there is no effect from sensible or latent heat capacity. It should be noted that material properties for the $\mathrm{CW}$ composites did not depend on the phase state of the wax. Under this assumption, increasing the metal mass fraction resulted in improved performance due to the increased thermal conductivity. This is seen by comparing $\mathrm{CW} 5 \%$ to CW 30\%, where increased metal content results in improved performance for the CW 30\%. Similarly, the aluminum block $(\mathrm{AB})$ design outperformed the $\mathrm{CW}$ composites due to having higher conductivity.

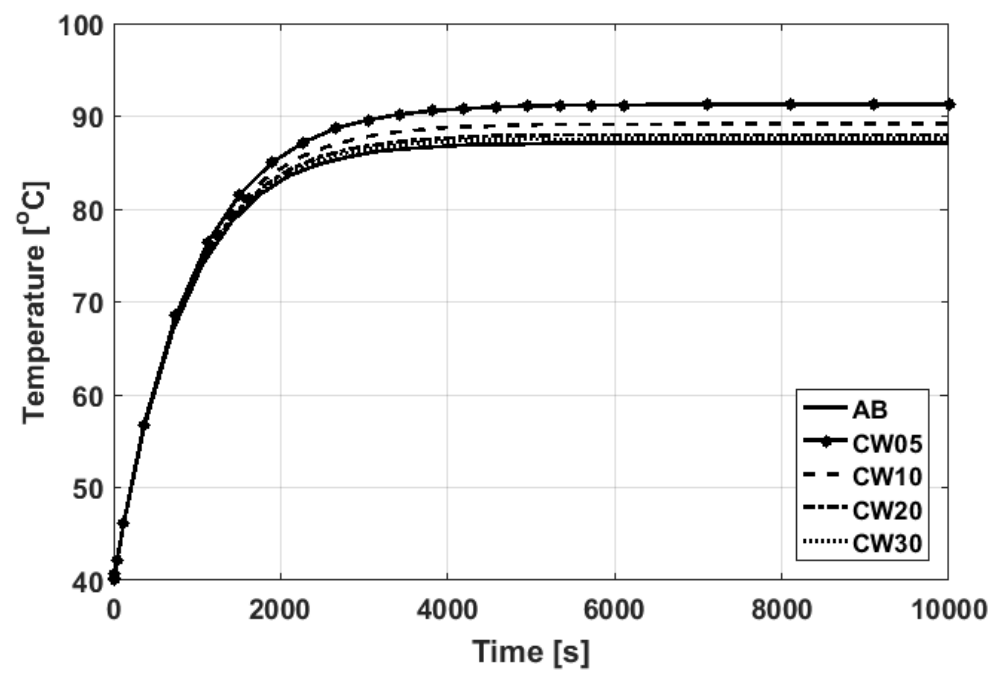

Figure 7: Cell core temperatures under $65 \mathrm{~W} /$ cell heating rate for the block having $10 \mathrm{~mm}$ spacing. Temperatures increase from rest, at $40^{\circ} \mathrm{C}$, to steady state conditions by the end of simulation. 

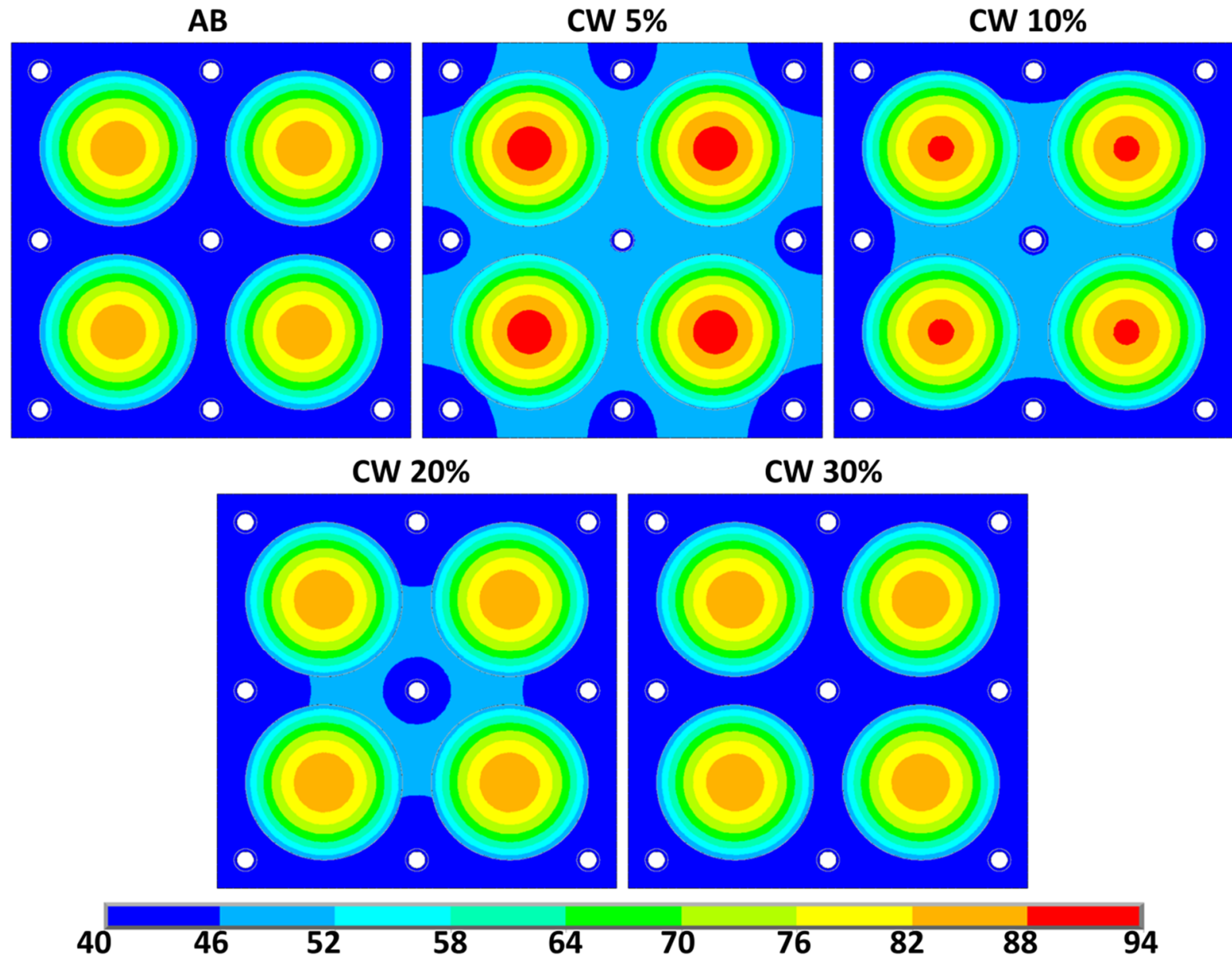

Figure 8: Steady-state temperature contour plots for the block having $10 \mathrm{~mm}$ cell spacing.

\subsection{Effect of Thermal Conductivity}

The steady state core temperature was plotted as a function of block conductivity in Figure 9. The figure shows about the highest sensitivity of core temperature to thermal conductivity for $\mathrm{k}<100 \mathrm{~W} \cdot \mathrm{m}^{-1} \cdot \mathrm{K}^{-1}$. Increasing conductivity beyond this value has little effect on the steady state core temperatures. The conductive time constant of the block, defined as the time it takes for the core temperature to reach $63 \%$ of the steady state value, is also shown in Figure 9. It should be noted that the density and specific heat capacity were held constant. It was found that the time constant was on the order of 900 seconds. And, the change in time constant with block conductivity followed the same trend as the core temperature where large reductions in time constant were observed for $\mathrm{k}<100 \mathrm{~W} \cdot \mathrm{m}^{-1} \cdot \mathrm{K}^{-1}$. 


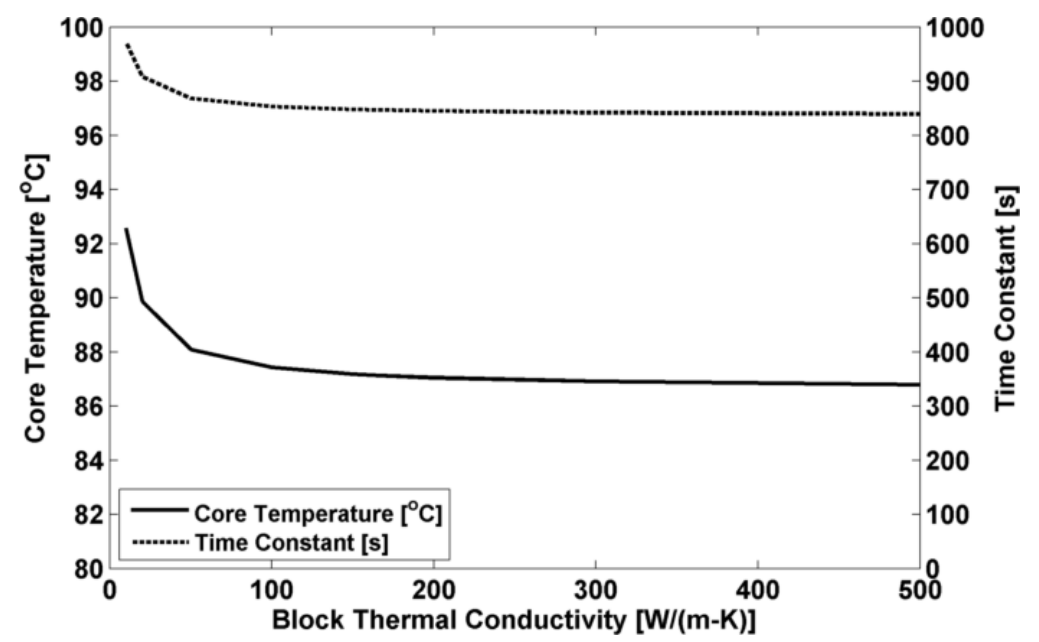

Figure 9: Effect of block conductivity on steady state core temperature and time constant for the block having $10 \mathrm{~mm}$ cell spacing. The TCC values are $1000 \mathrm{~W} \cdot \mathrm{m}^{-2} \cdot \mathrm{K}^{-1}$ between cell and block and $5000 \mathrm{~W} \cdot \mathrm{m}^{-}$ ${ }^{2} \cdot \mathrm{K}^{-1}$ between tube and block.

\subsection{Effect of Thermal Contact Conductance}

In order to evaluate the effect of interfacial thermal conductance, the block conductivity was held constant at $167 \mathrm{~W} \cdot \mathrm{m}^{-1} \cdot \mathrm{K}^{-1}$ and the TCC values were varied. Again, the block specific heat capacity and density were unchanged from that of Aluminum. In the case of varying the tube-to-block TCC, the cell-to-block TCC was held constant at $1000 \mathrm{~W} \cdot \mathrm{m}^{-2} \cdot \mathrm{K}^{-1}$. And in the case of varying the cell-to-block TCC, the tube-toblock TCC was held constant at $5000 \mathrm{~W} \cdot \mathrm{m}^{-2} \cdot \mathrm{K}^{-1}$. The recorded steady state core cell temperatures and calculated time constants are shown in Figure 10. The figure shows that increasing the tube-to-block TCC results in significant improvement up to about $5000 \mathrm{~W} \cdot \mathrm{m}^{-2} \cdot \mathrm{K}^{-1}$ and that increasing the cell-to-block TCC results in significant improvement up to about $2000 \mathrm{~W} \cdot \mathrm{m}^{-2} \cdot \mathrm{K}^{-1}$. Also shown is the visible difference in size when comparing the two curves. The y-axis range of the cell-to-block TCC curve represents an improvement of less than $4^{\circ} \mathrm{C}$ from $10 \mathrm{~W} \cdot \mathrm{m}^{-2} \cdot \mathrm{K}^{-1}$ to $20,000 \mathrm{~W} \cdot \mathrm{m}^{-2} \cdot \mathrm{K}^{-1}$ whereas that of the tube-to-block curve shows an improvement of approximately $10^{\circ} \mathrm{C}$. 

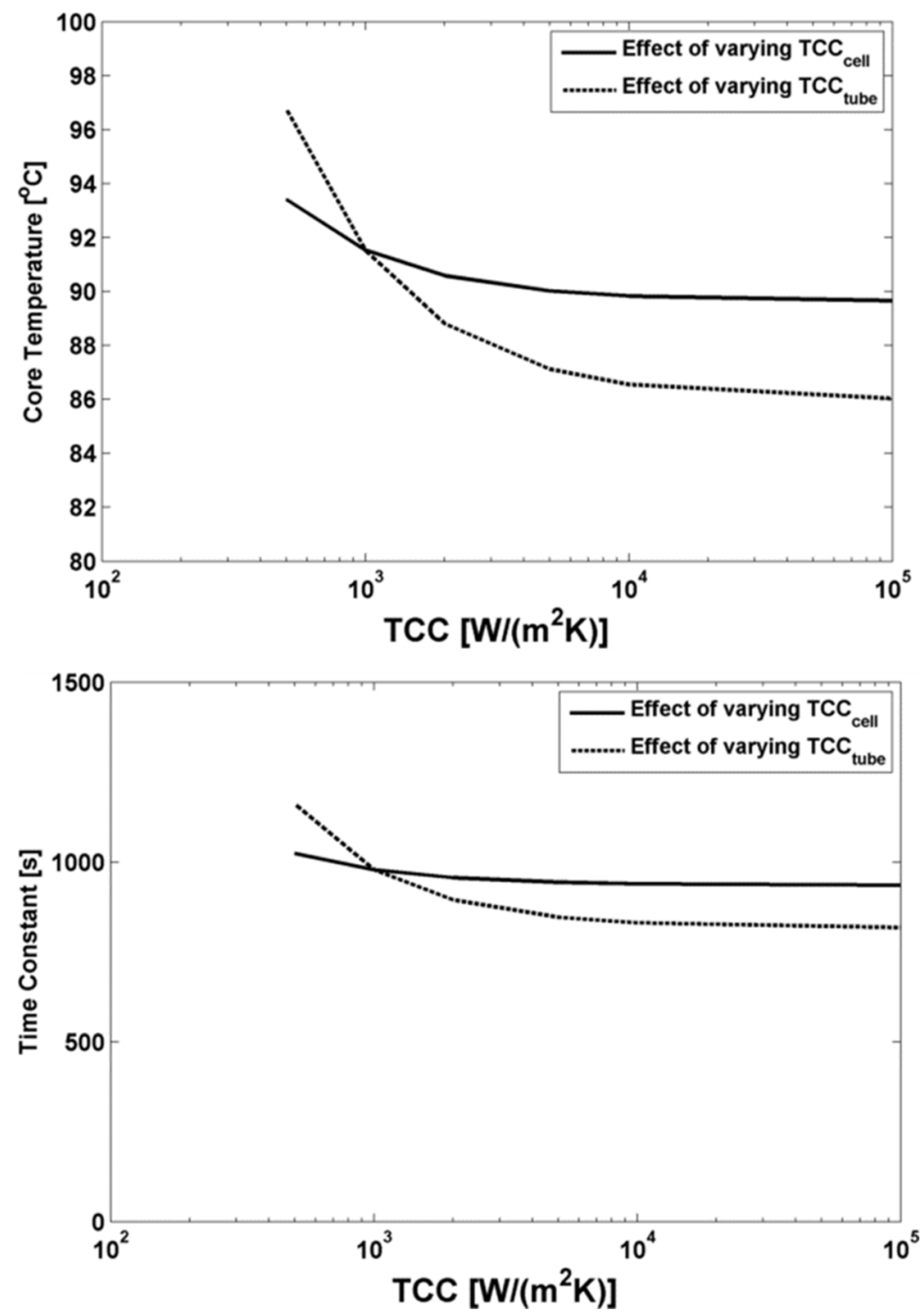

Figure 10: Effect of thermal contact conductance (TCC) on steady state core temperature (top) and time constant (bottom) for the block having $10 \mathrm{~mm}$ cell spacing. The block thermal conductivity is held constant at $167 \mathrm{~W} \cdot \mathrm{m}^{-1} \cdot \mathrm{K}^{-1}$.

\subsection{Composite Composition and Melting Temperature}

The effect of composition (ratio of wax to conductive filler) in composite blocks was evaluated for three different wax melting temperatures of $57^{\circ} \mathrm{C}, 51^{\circ} \mathrm{C}$, and $45^{\circ} \mathrm{C}$. Steady state core cell temperatures were recorded and time constants were calculated. Interfacial properties were held constant, but material properties changed with composition as shown in Table 1. With increased wax percentage, the latent heat capacity increases, block thermal conductivity decreases, density decreases, and specific heat capacity increases. The steady state core temperatures, shown in Figure 11, were dependent on block composition but not on the wax melting temperature. As mentioned previously, it was assumed that there was no difference in material properties for the solid, partially-melted, or liquid regions. And, circulation of liquid wax within the block was neglected as well. As such, there was less than $0.1 \%$ difference in steady state core temperatures when the melting temperature was varied from $57^{\circ} \mathrm{C}$ to $45^{\circ} \mathrm{C}$, and therefore only 
one set of data is shown for core temperatures in Figure 11. The time constants, however, were sensitive to the block melting temperature and block composition. For low fraction of conductive filler material, the block thermal conductivity was lower which resulted in larger temperature gradients through the block. Inspection of Figure 8 shows that the less conductive composite blocks may have regions where the wax is melted or partially-melted, especially for the melting temperature of $45^{\circ} \mathrm{C}$. For the $\mathrm{CW} 30 \%$ block, on the other hand, the thermal conductivity was high enough to keep the block below $57^{\circ} \mathrm{C}$, meaning that the cooling tubes were keeping the block cool enough to prevent melting of the wax. The CW 30\% material, therefore, showed virtually no change in time constant for the three different melting temperatures.

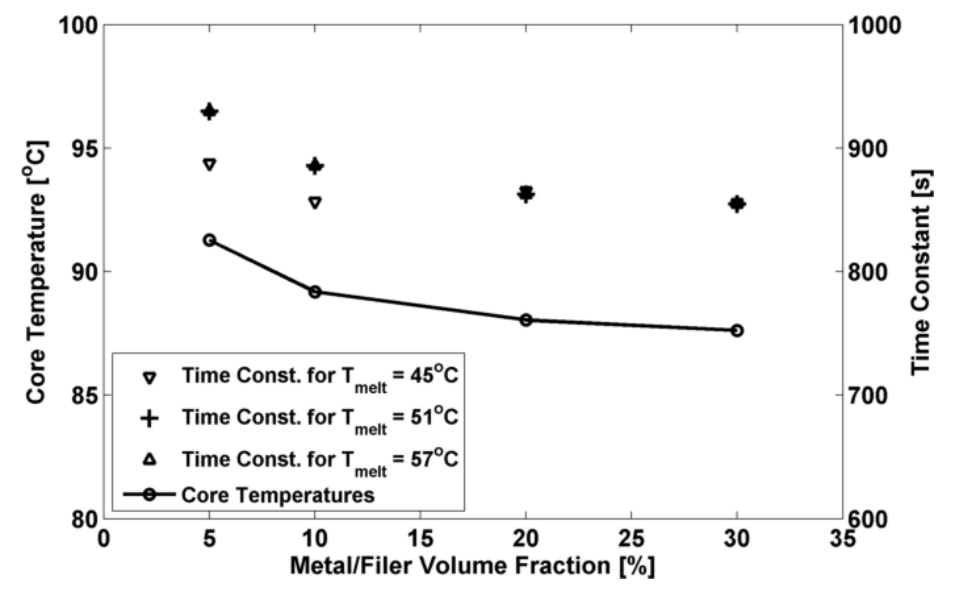

Figure 11: Effect of metal volume fraction on steady state core temperature and time constant for the block having $10 \mathrm{~mm}$ cell spacing.

\subsection{Cell to Cell Spacing and Failure Modes}

In the previous sections, the largest spacing (10 $\mathrm{mm}$ between cells and between cell and block edge) geometry was used. In this section, spacing is decreased to medium $(5 \mathrm{~mm})$ and small $(1 \mathrm{~mm})$ spacing and is compared to the results of the large spacing. All three modes are used to evaluate the performance of each material. The effect of cell spacing on steady state performance is shown in Table 2. The steady state temperatures and time constants are given for each material and for each geometry. In comparing the three geometries, the core temperature decreases slightly as spacing is increased. Decreasing spacing from $10 \mathrm{~mm}$ to $1 \mathrm{~mm}$ between cells resulted in less than $1{ }^{\circ} \mathrm{C}$ temperature rise at the core. As with previous results, the performance of the materials is directly proportional to block conductivity.

Table 2: Effect of cell spacing on steady state temperatures and time constants.

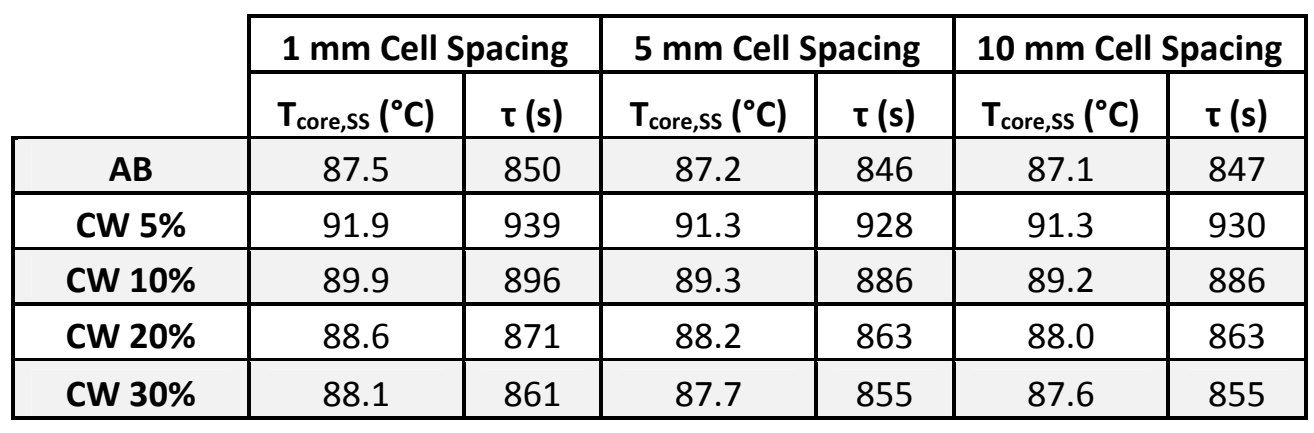


The same analysis was run using the slow, low energy load profile. In addition to recording core temperature, the temperature of the neighboring cell was also recorded. The location of this measurement was at the position closest to the failed cell, as illustrated in Figure 12. The slow, low energy load profile is initiated with the system at steady state, under normal load conditions. At $t=0 \mathrm{~s}$, the neighboring cells are secured and their heat generation is set to zero. Simultaneously, the failed cell begins its slow exothermic reaction, releasing energy along the profile shown in Figure 6. An example of the transient failed cell core temperature is shown in Figure 13. Spacing was found to have little to no effect on the core temperature experienced by the failed cell. The neighbor edge temperatures are shown in Figure 14. The peak temperatures and time at which they were reached are given in Table 3. It was found that spacing has a larger effect with higher percent wax materials. Similar to steady state results, block conductivity was the dominant factor in block performance. The aluminum block showed the lowest temperatures, followed by the CW $30 \%$ block.

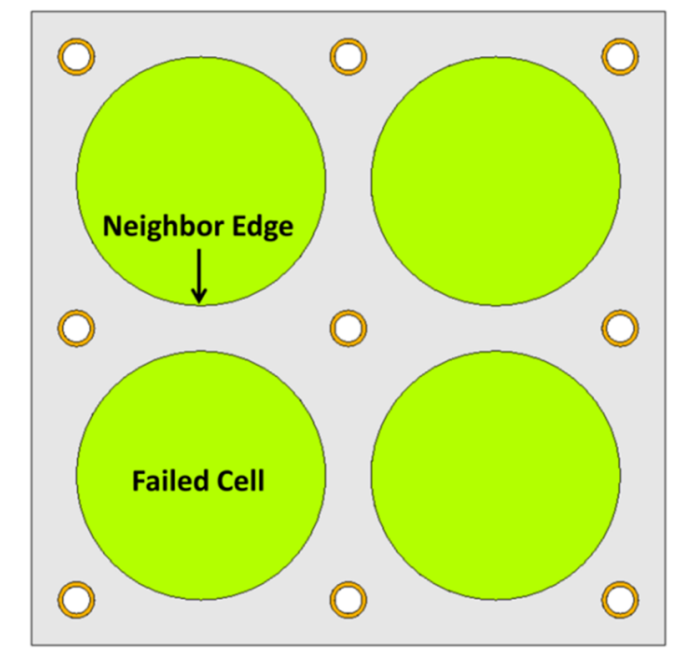

Figure 12: Simple cold block model diagram, showing the failed cell and the location of the nearest neighbor edge temperature measurement. 


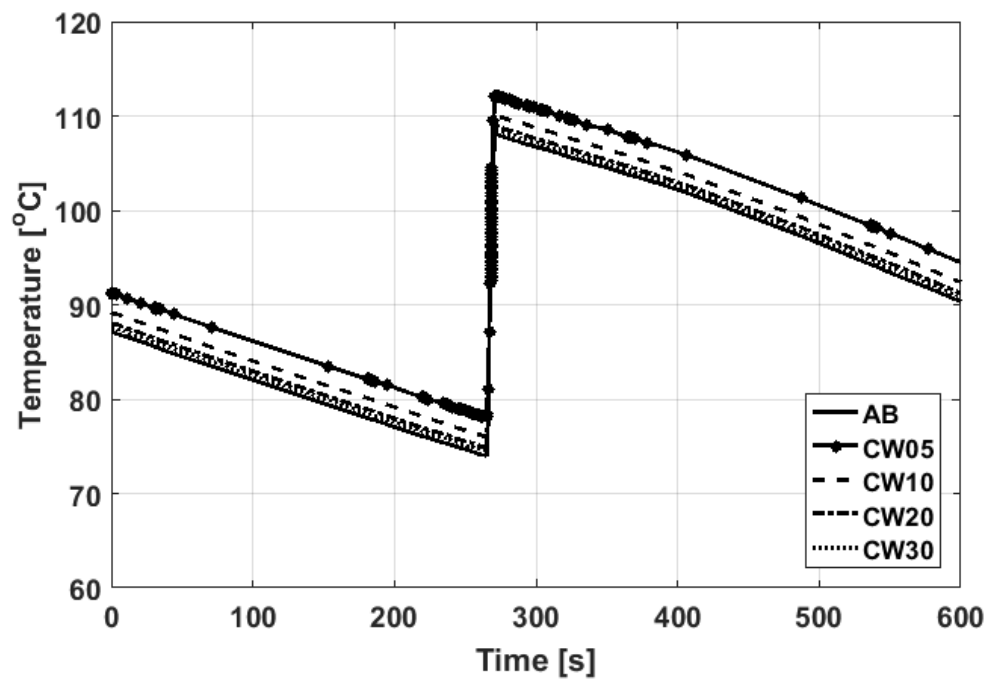

Figure 13: Core temperature of the failed cell during the slow, low energy failure profile. The effect of block material is shown for the block having $10 \mathrm{~mm}$ spacing. 

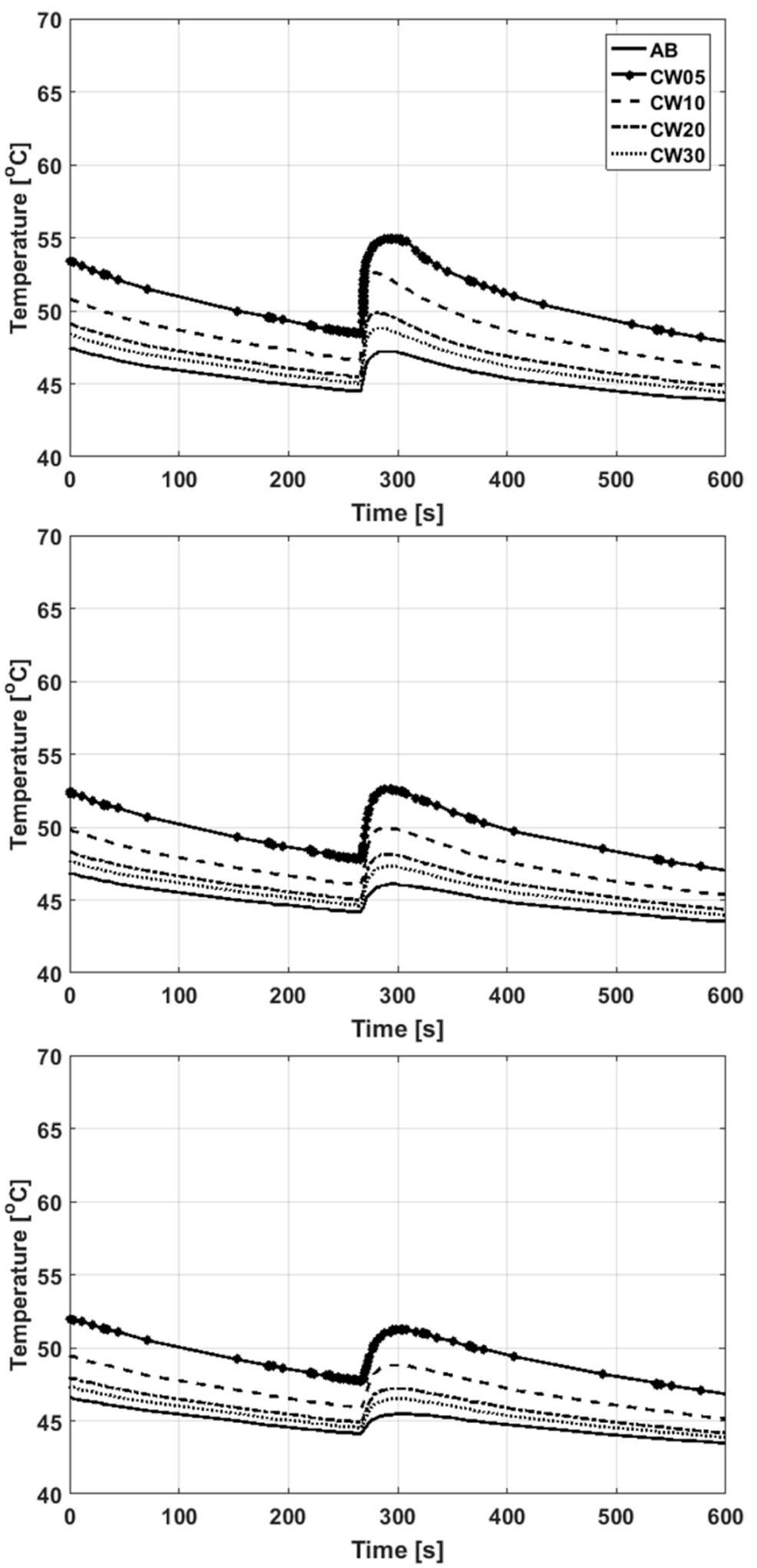

Figure 14: Temperatures at closest edge of neighbor during the slow, low energy reaction simulation for each block material at various spacing: $1 \mathrm{~mm}$ (top), $5 \mathrm{~mm}$ (middle), and $10 \mathrm{~mm}$ (bottom). 
Table 3: Maximum core temperatures of the failed cell recorded during the slow, low energy reaction simulation.

\begin{tabular}{|c|c|c|c|c|c|c|}
\hline & \multicolumn{2}{|c|}{$1 \mathrm{~mm}$ Cell Spacing } & \multicolumn{2}{|c|}{$5 \mathrm{~mm}$ Cell Spacing } & \multicolumn{2}{|c|}{$10 \mathrm{~mm}$ Cell Spacing } \\
\hline & $\mathrm{T}_{\text {peak }}\left({ }^{\circ} \mathrm{C}\right)$ & Time (s) & $\mathrm{T}_{\text {peak }}\left({ }^{\circ} \mathrm{C}\right)$ & Time (s) & $\mathrm{T}_{\text {peak }}\left({ }^{\circ} \mathrm{C}\right)$ & Time $(s)$ \\
\hline$A B$ & 47.2 & 288 & 46.1 & 298 & 45.5 & 305 \\
\hline CW 5\% & 54.9 & 295 & 52.6 & 288 & 51.2 & 304 \\
\hline CW $10 \%$ & 52.6 & 278 & 50.0 & 288 & 48.8 & 298 \\
\hline CW 20\% & 49.9 & 281 & 48.1 & 288 & 47.2 & 298 \\
\hline CW $30 \%$ & 48.8 & 284 & 47.3 & 293 & 46.5 & 298 \\
\hline
\end{tabular}

The fast, high energy reaction analysis was simulated and both core and neighbor edge temperatures were recorded. The load profile as described previously is initiated with the system at steady state from normal operation. However, the system is not shut off and the three operational cells continue to produce 65 $\mathrm{W} /$ cell of heat as the failed cell dissipates its energy over $5 \mathrm{~s}$. The simulation is run to $\mathrm{t}=300 \mathrm{~s}$ in order to observe the ability of the cold block to manage the great amount of heat released during failure. The neighbor edge temperatures are shown in Figure 15 where spacing increases from top to bottom, the full time of $\mathrm{t}=0$ to $300 \mathrm{~s}$ is shown in the graphs at left, and zoomed-in graphs from $\mathrm{t}=0$ to $30 \mathrm{~s}$ are shown in the graphs at right. Peak temperatures and times are given in Table 4. The effects of cell spacing had significant influence on the block performance during this fast, high energy reaction. For example, the duration of wax melting is much longer for cell to cell spacing of $10 \mathrm{~mm}$ compared with that of $1 \mathrm{~mm}$. This indicates that the amount of wax available for absorbing heat during melting is reduced at the reduced spacing, which is also evident in the peak temperature of the neighbor cell increasing from 80.5 ${ }^{\circ} \mathrm{C}$ for the $10 \mathrm{~mm}$ spacing $\mathrm{CW} 5 \%$ block to $118.1^{\circ} \mathrm{C}$ for the $1 \mathrm{~mm}$ spacing $\mathrm{CW} 5 \%$ block. 

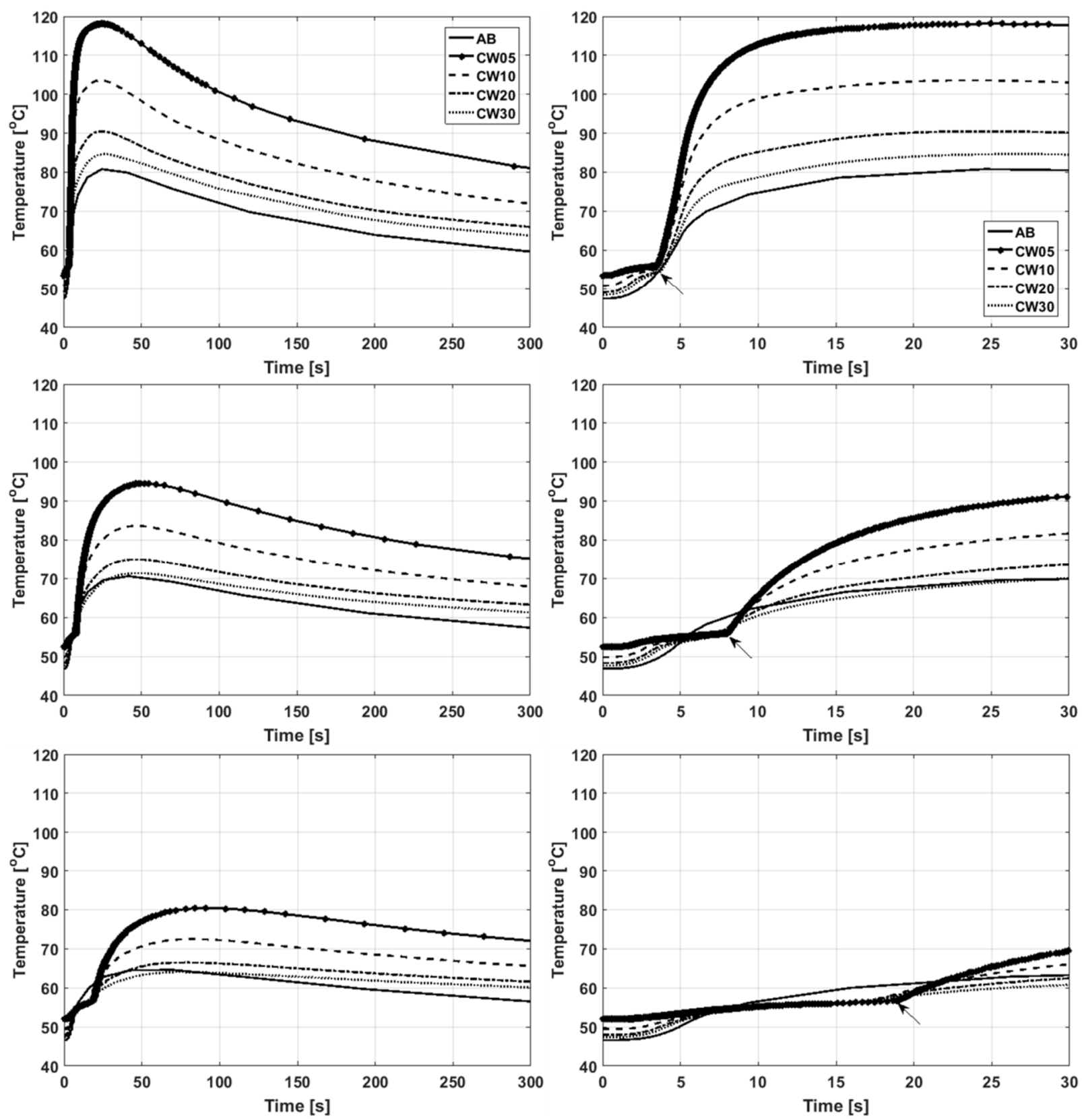

Figure 15: Temperatures at closest edge of neighbor during the fast, high energy reaction simulations for each block material at various spacing: $1 \mathrm{~mm}$ (top), $5 \mathrm{~mm}$ (middle), and $10 \mathrm{~mm}$ (bottom). Data is shown for $t=0$ to $300 \mathrm{~s}$ (left) and the same data is cropped from $t=0$ to $30 \mathrm{~s}$ (right). Arrows point out the effect of wax melting. The $A B$ curve does not experience a plateau at $57^{\circ} \mathrm{C}$ as it does not include latent heat storage. 
Table 4: Maximum temperatures of the failed cell recorded during the fast, high energy reaction simulation.

\begin{tabular}{|c|c|c|c|c|c|c|}
\hline & \multicolumn{2}{|c|}{$1 \mathrm{~mm}$ Cell Spacing } & \multicolumn{2}{|c|}{$5 \mathrm{~mm}$ Cell Spacing } & \multicolumn{2}{|c|}{$10 \mathrm{~mm}$ Cell Spacing } \\
\hline & $\mathrm{T}_{\text {peak }}\left({ }^{\circ} \mathrm{C}\right)$ & Time (s) & $\mathrm{T}_{\text {peak }}\left({ }^{\circ} \mathrm{C}\right)$ & Time (s) & $\mathrm{T}_{\text {peak }}\left({ }^{\circ} \mathrm{C}\right)$ & Time (s) \\
\hline$A B$ & 80.8 & 25 & 70.6 & 42 & 64.6 & 70 \\
\hline CW 5\% & 118.1 & 25 & 94.5 & 52 & 80.5 & 91 \\
\hline CW 10\% & 103.6 & 23 & 83.7 & 47 & 72.5 & 79 \\
\hline CW $20 \%$ & 90.5 & 24 & 75.0 & 45 & 66.5 & 79 \\
\hline CW $30 \%$ & 84.7 & 27 & 71.4 & 48 & 64.1 & 72 \\
\hline
\end{tabular}

To further investigate the effect of spacing and material properties under failure conditions, Figure 16 shows snapshots of the system at 2, 6, 10,20, and 50 seconds. The coloring is based on the melting of wax, which begins at $55^{\circ} \mathrm{C}$, peaks at $57^{\circ} \mathrm{C}$, and ends at $59^{\circ} \mathrm{C}$. The blue areas represent temperatures under $55^{\circ} \mathrm{C}$ (not melted in the case of wax composites), the green areas represent temperatures between 55 and $59^{\circ} \mathrm{C}$ (partially-melted), and the red areas represent temperatures over $59^{\circ} \mathrm{C}$ (completely melted). Also shown is the temperature at the edge of the neighboring cell in each contour plot. CW 5\% was chosen to represent the wax composite since it has the highest percentage of wax and therefore will most clearly demonstrate the effect of wax. This was compared to $\mathrm{AB}$ which has no wax and instead uses high thermal conductivity to manage heat. The heat transfer mechanisms of storing heat during wax melting versus dissipating heat with a high thermal conductivity block are quite different. The contour plots and neighbor edge temperatures illustrate this in several ways. The partially-melted region is thinner and the melted region is smaller in the case of $\mathrm{CW}$, indicating higher thermal gradients within the block. This is because rather than quickly dispersing the heat as in the case of highly thermally conductive material, the wax absorbs the heat energy, melts, and holds it in. This works well to isolate the heat produced by the failed cell; however, the isolation fails when the melting band reaches the neighboring cell. As such, spacing in wax composite materials is very significant and should be designed around the expected failure characteristics of the cells. In order for the merits of wax composite designs to be realized, there must be enough volume of wax in between cells to absorb the heat from cell failure without allowing the heat to reach the next cell. On the other hand, high thermal conductivity designs such as AB quickly disperse the heat, allowing it to reach the cooling tubes and exit the system sooner. Even at $1 \mathrm{~mm}$ cell to cell spacing, the present work showed that the heat transfer path to the coolant was enough to dissipate the large energy release before heat was able to conduct across the short cell to cell distance.

Previous studies have investigated the use of phase change materials without cooling tubes, in which case the heat-trapping merit of wax composites is very attractive [31, 33, 7, 42, 39, 37]. However, in applications where indirect liquid cooling is used, the present results indicate that attention should be given to increasing block conductivity and interface quality. Even at very close cell to cell spacing, high conductivity blocks are found to dissipate heat quickly to the coolant without spreading heat to neighboring cells. 
Time $\quad$ CW 5\%, $1 \mathrm{~mm}$

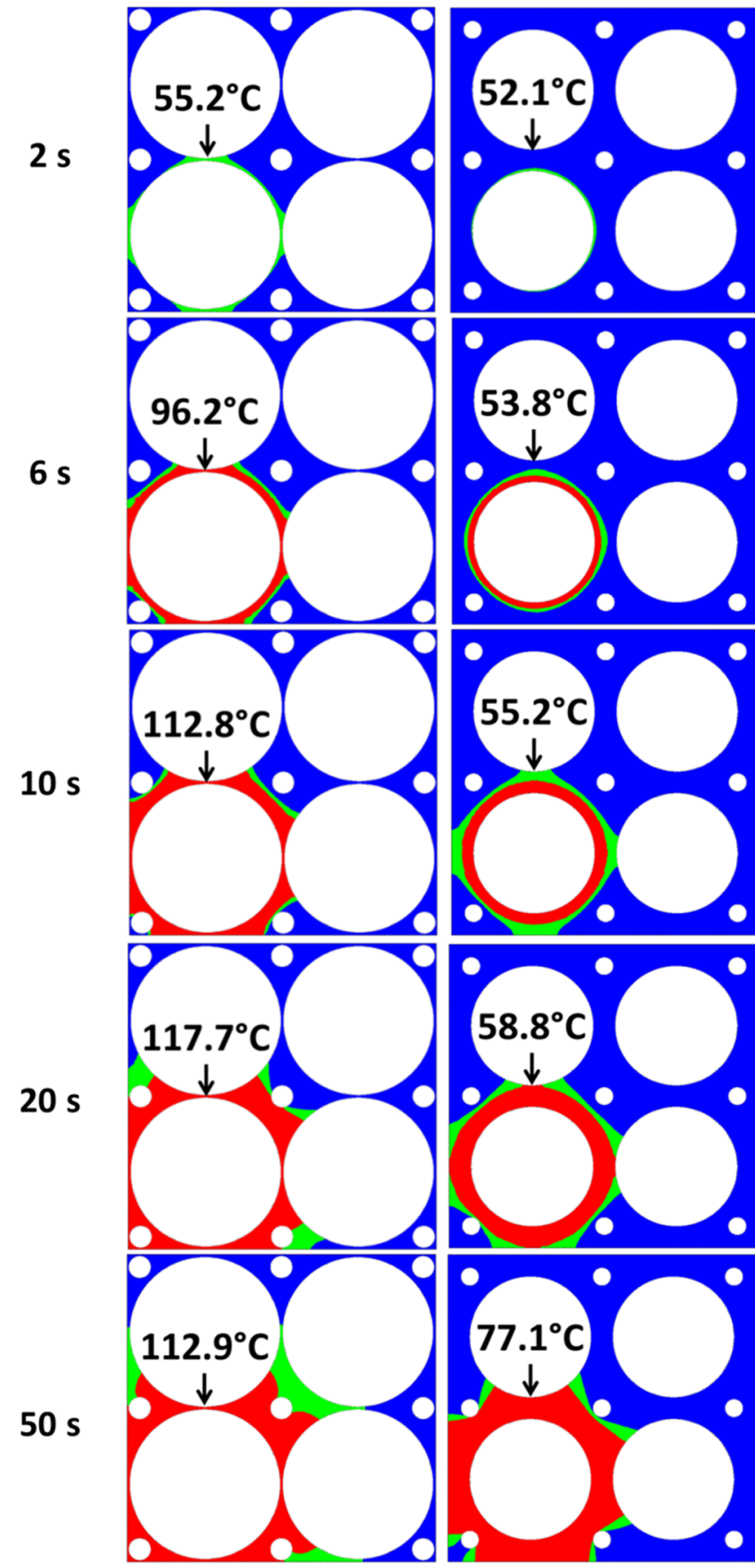

$\mathrm{AB}, 1 \mathrm{~mm}$

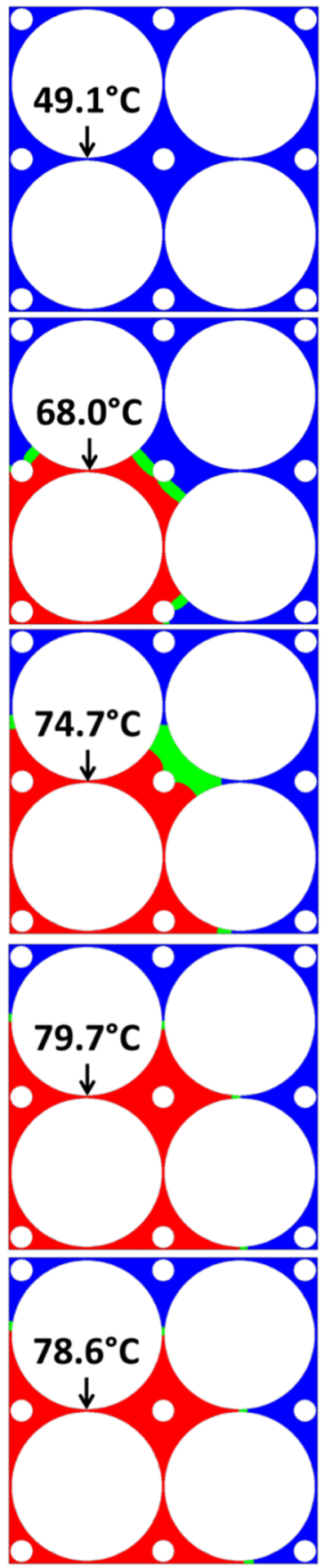

$A B, 10 \mathrm{~mm}$

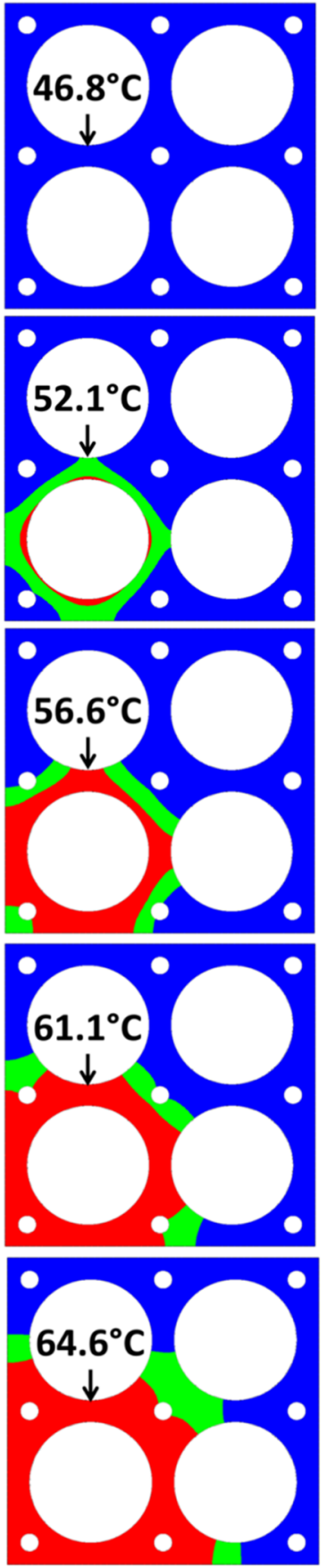

Figure 16: Contour plots of $\mathrm{CW} 5 \%$ and $\mathrm{AB}$ designs under fast, high energy reaction. Snapshots are taken at various times up to $50 \mathrm{~s}$. Blue represents temperatures under $55^{\circ} \mathrm{C}$ (solid wax for $\mathrm{CW}$ simulations), green represents temperatures between 55 and $59^{\circ} \mathrm{C}$ (partially-melted region for $\mathrm{CW}$ simulations), and red represents temperatures over $59^{\circ} \mathrm{C}$ (liquid wax for $\mathrm{CW}$ simulations). 


\section{Conclusions}

Two different materials for fluid-cooled block thermal management of cylindrical lithium-ion cells for large-scale energy storage were evaluated using finite element modeling of a simple geometry with consistent conditions. The designs included a solid aluminum block (AB) and a composite material with varying amounts of wax $(\mathrm{CW})$. The effects of cell spacing as well as bulk thermal conductivity of the cold block, thermal resistance at the material interfaces, and heat storage of the cold block were considered.

Results indicate that the most critical factor in design of battery thermal management equipment is how easily heat is transferred to the cooling tubes and removed from the system. Block conductivity and interface quality both had similar impact on steady state temperatures. The $\mathrm{AB}$ block and $\mathrm{CW}$ blocks with higher fraction of conductive filler performed well because of their high block conductivity. In the present configuration, where the area of cooling tubes was lower than the area of the cells, it was found that the interface quality at the cooling tubes was more important than those at the cells. This effect should be investigated in future work for different cooling tube and packing factor arrangements.

Spacing was significant in designs with incorporated heat storage in the material, i.e. the CW materials. In order for the heat storage to succeed in absorbing heat and preventing heat propagation to neighboring cells, there must be enough wax between cells to absorb heat from failures. In compact designs, the small amount of wax melts quickly and heat is allowed to spread to neighboring cells. On the other hand, the $\mathrm{AB}$ design performed well by quickly dissipating heat to the coolant rather than relying on heat storage in the latent heat of wax melting. This effect should also be considered further, again, in regards to different cooling tube and packing factor arrangements.

When considering system design, heat sink size, weight, and thermal performance must all be considered. Composite materials may appear attractive from a weight perspective, as block density may be reduced by up to $60 \%$ relative to aluminum when using a composite with $5 \%$ metal filler. However, results in the present work indicate that a wider cell-to-cell spacing may be required to achieve similar thermal performance as a solid aluminum heat sink.

\section{Acknowledgements}

The authors would like to acknowledge ONR and the NAVSEA Naval Innovative Science and Engineering (NISE) Program for supporting this work. The views, opinions, and findings should not be construed as representing the official position of either the Department of Defense or the sponsoring organizations. 


\section{References}

[1] R. Liu, J. Chen, J. Xun, K. Jiao and Q. Du, "Numerical investigation of thermal behaviors in lithiumion battery stack discharge," Applied Energy, vol. 132, pp. 288-297, 2014.

[2] M.-S. Wu, K. H. Liu, Y.-Y. Wang and C.-C. Wan, "Heat dissipation design for lithium-ion batteries," J. Power Sources, vol. 109, pp. 160-166, 2002.

[3] S. Mohammadian and Y. Zhang, "Thermal management optimization of an air-cooled Li-ion battery module using pin-fin heat sinks for hybrid electric vehicles," J. Power Sources, vol. 273, pp. 431439, 2015.

[4] J. Xun, R. Liu and K. Jiao, "Numerical and analytical modeling of lithium ion battery thermal behaviors with different cooling designs," J. Power Sources, vol. 233, pp. 47-61, 2013.

[5] L. Fan, J. M. Khodadadi and A. A. Pesaran, "A parametric study on thermal management of an aircooled lithium-ion battery module for plug-in hybrid electric vehicles," J. Power Sources, vol. 238, pp. 301-312, 2013.

[6] H. Park, "A design of air flow configuration for cooling lithium ion battery in hybrid electric vehicles," J. Power Sources, vol. 239, pp. 20-36, 2013.

[7] R. Kizilel, R. Sabbah, J. R. Selman and S. Al-Hallaj, "An alternative cooling system to enhance the safety of Li-ion battery packs," J. Power Sources, vol. 194, pp. 1105-1112, 2009.

[8] T. D. Hatchard, D. D. MacNeil, D. A. Stevens, L. Christensen and J. R. Rahn, "Importance of heat transfer by radiation in li-ion batteries during thermal abuse," Electrochemical and Solid State Letters, vol. 3, no. 7, pp. 305-308, 2000.

[9] D. Chen, J. Jiang, G. Kim, C. Yang and A. Pesaran, "Comparison of different cooling methods for lithium ion battery cells," Applied Thermal Engineering, vol. 94, pp. 846-854, 2016.

[10] G. Karimi and A. Dehghan, "Thermal analysis of high-power lithium-ion battery packs using flow network approach," Int. J. Energy Research, vol. 38, no. 14, pp. 1793-1811, 2014.

[11] N. Nieto, L. Diaz, J. Gastelurrutia, F. Blanco, J. Ramos and A. Rivas, "Novel thermal management system design methodology for power lithium-ion battery," J. Power Sources, vol. 272, pp. 291-302, 2014.

[12] J. Smith, M. Hinterberger, P. Hable and J. Koehler, "Simulative method for determining the optimal operating conditions for a cooling plate for lithium-ion battery cell modules," J. Power Sources, vol. 267, pp. 784-792, 2014. 
[13] W. Tong, K. Somasundaram, E. Birgersson, A. Mujumdar and C. Yap, "Numerical investigation of water cooling for a lithium-ion bipolar battery pack," Int. J. Therm. Sci., vol. 94, pp. 259-269, 2015.

[14] L. Jin, P. Lee, X. Kong, Y. Fan and S. Chou, "Ultra-thin minichannel LCP for EV battery thermal management," Applied Energy, vol. 113, pp. 1786-1794, 2014.

[15] Y. Huo, Z. Rao, X. Liu and J. Zhao, "Investigation of power battery thermal management by using mini-channel cold plate," Energy Conversion and Management, vol. 89, pp. 387-395, 2015.

[16] J. Zhao, Z. Rao and Y. Li, "Thermal performance of mini-channel liquid cooled cylinder based battery thermal management for cylindrical lithium-ion power battery," Energy Conversion and Management, vol. 103, pp. 157-165, 2015.

[17] A. Jarrett and I. Kim, "Design optimization of electric vehicle battery cooling plates for thermal performance," J. Power Sources, vol. 196, pp. 10359-10368, 2011.

[18] A. Jarrett and I. Kim, "Influence of operating conditions on the optimum design of electric vehicle battery cooling plates," J. Power Sources, vol. 245, pp. 644-655, 2014.

[19] H. Hirano, T. Tajima, T. Hasegawa, T. Sekiguchi and M. Uchino, "Boiling liquid battery cooling for electric vehicle," in ITEC Asia-Pacific, Beijing, 2014.

[20] T. Tran, S. Harmand, B. Desmet and S. Filangi, "Experimental investigation on the feasibility of heat pipe cooling for HEV/EV lithium-ion battery," Applied Thermal Engineering, vol. 63, pp. 551-558, 2014.

[21] Z. Rao, S. Wang, M. Wu, Z. Lin and F. Li, "Experimental investigation on thermal management of electric vehicle battery with heat pipe," Energy Conversion and Management, vol. 65, pp. 92-97, 2013.

[22] Z. Rao, Y. Huo and X. Liu, "Experimental study of an OHP-cooled thermal management system for electric vehicle power battery," Exp. Therm. Fluid Sci., vol. 57, pp. 20-26, 2014.

[23] G. Burban, V. Ayel, A. Alexandre, P. Lagonotte, Y. Bertin and R. C., "Experimental investigation of a pulsating heat pipe for hybrid vehicle applications," Applied Thermal Engineering, vol. 50, pp. 94$103,2013$.

[24] A. Greco, D. Cao, X. Jiang and H. Yang, "A theoretical and computational study of lithium-ion battery thermal management for electric vehicles using heat pipes," J. Power Sources, vol. 257, pp. 344-345, 2014.

[25] R. Zhao, J. Gu and J. Liu, "An experimental study of heat pipe thermal management system with wet cooling method for lithium ion batteries," J. Power Sources, vol. 273, pp. 1089-1097, 2015.

[26] N. Javani, I. Dincer, G. Naterer and B. Yilbas, "Heat transfer and thermal management with PCMs in 
a Li-ion battery cell for electric vehicles," Int. J. Heat and Mass Transfer, vol. 72, pp. 690-703, 2014.

[27] N. Javani, I. Dincer, G. Naterer and G. Rohrauer, "Modeling of passive thermal management for electric vehicle battery packs with PCM between cells," Applied Thermal Engineering, vol. 73, pp. 307-316, 2014.

[28] M. Ramandi, I. Dincer and G. Naterer, "Heat transfer and thermal management of electric vehicle batteries with phase change materials," Heat. Mass Transf., vol. 47, pp. 777-788, 2011.

[29] A. Alrashdan, A. Mayyas and S. Al-Hallaj, "Thermo-mechanical behaviors of the expanded graphitephase change material matrix used for thermal management of Li-ion battery packs," J. Mater. Process. Tech., vol. 210, pp. 174-179, 2010.

[30] A. Greco, X. Jiang and D. Cao, "An investigation of lithium-ion battery thermal management using paraffin/porous-graphite-matrix composite," J. Power Sources, vol. 278, pp. 50-68, 2015.

[31] S. Al Hallaj and J. R. Selman, "A novel thermal management system for EV batteries using phase change material (PCM)," J. Electrochem. Soc., vol. 147, pp. 3231-3236, 2000.

[32] S. Al Hallaj and J. Selman, "Thermal modeling of secondary lithium batteries for electric vehicle/hybrid electric vehicle applications," J. Power Sources, vol. 110, pp. 341-348, 2002.

[33] A. Mills and S. Al-Hallaj, "Simulation of passive thermal management system for lithium-ion battery packs," J. Power Sources, vol. 141, pp. 307-315, 2005.

[34] A. Mills, M. Farin, J. Selman and S. Al-Hallaj, "Thermal conductivity enhancement of phase change materials using a graphite matrix," Applied Thermal Engineering, vol. 26, pp. 1652-1661, 2006.

[35] R. Kizilel, A. Lateef, R. Sabbah, M. Farid, J. Selman and S. Al-Hallaj, "Passive control of temperature excursion and uniformity in high-energy Li-ion battery packs at high current and ambient temperature," J. Power Sources, vol. 183, pp. 370-375, 2008.

[36] S. Khateeb, M. Farid, J. Selman and S. Al-Hallaj, "Design and simulation of a lithium-ion battery with a phase change material thermal management system for an electric scooter," J. Power Sources, vol. 128, pp. 292-307, 2004.

[37] S. Khateeb, S. Amiruddin, M. Farid, J. R. Selman and S. Al-Hallaj, "Thermal management of Li-ion battery with phase change material for electric scooters: experimental validation," J. Power Sources, vol. 142, pp. 345-353, 2005.

[38] P. Zhang, Z. Meng, H. Zhu, Y. Wang and S. Peng, "Experimental and numerical study of heat transfer characteristics of a paraffin/metal foam composite PCM," Energy Procedia, vol. 75, pp. 3091-3097, 2015. 
[39] W. Q. Li, Z. G. Qu, Y. L. He and Y. B. Tao, "Experimental study of a passive thermal management system for high-powered lithium ion batteries using porous metal foam saturated with phase change materials," J. Power Sources, vol. 255, pp. 9-15, 2014.

[40] Z. Qu, W. Li, J. Wang and W. Tao, "Passive thermal management using metal foam saturated with phase change material in a heat sink," International Communications in Heat and Mass Transfer, vol. 39, pp. 1546-1549, 2012.

[41] Z. Qu, W. Li and W. Tao, "Numerical model of the passive thermal management system for highpower lithium ion battery by using porous metal foam saturated with phase change material," Interational Journal of Hydrogen Energy, vol. 39, pp. 3904-3913, 2014.

[42] R. Zhao, S. Zhang, J. Gu, J. Liu, S. Carkner and E. Lanoue, "An experimental study of lithium ion battery thermal management using flexible hydrogel films," J. Power Sources, vol. 255, pp. 29-36, 2014.

[43] S. Zhang, R. Zhao, J. Liu and J. Gu, "Investigation on a hydrogel based passive thermal management system for lithium ion batteries," Energy, vol. 68, pp. 854-861, 2014.

[44] R. Chiba, "A Series Solution for Heat Conduction Problem with Phase Change in a Finite Slab," Abstract and Applied Analysis, 2014.

[45] A. Bhattacharya, V. V. Calmidi and R. L. Mahajan, "Thermophysical properties of high porosity metal foams," ASME J. Heat Transfer, vol. 45, pp. 1017-1031, 2002.

[46] M. Fleckstein, "Current density and charge inhomogeneities in Li-ion battery cells with LiFePO4 as cathode material due to temperature gradients," J. Power Sources, vol. 196, 2011. 